\title{
A new infra-generic classification of the species-rich Neotropical genus Myrcia s.l.
}

\author{
E. J. Lucas ${ }^{1}$, B. S. Amorim ${ }^{2}$, D. F. Lima ${ }^{3}$, A. R. Lima-Lourenço ${ }^{1}$, E. M. Nic Lughadha ${ }^{1}$, C. E. B. Proença ${ }^{4}$, \\ P. O. Rosa ${ }^{5}$, A. S. Rosário ${ }^{6}$, L. L. Santos ${ }^{7}$, M. F. Santos ${ }^{8}$, M. C. Souza ${ }^{9}$, V. G. Staggemeier ${ }^{10}$, \\ T. N. C. Vasconcelos ${ }^{1} \&$ M. Sobral ${ }^{11}$
}

Summary. A new classification of the large Neotropical genus Myrcia s.l. is proposed. Nine sections are presented that correspond to recently published clades. Of these nine sections, sects. Myrcia, Aulomyrcia and Sympodiomyrcia are already published, sects. Reticulosae and Tomentosae are new sections, sect. Eugeniopsis is a new combination whilst sects. Aguava, Calyptranthes and Gomidesia are new combinations at a new rank (comb. \& stat. nov.). Six lectotypifications are made for sections or genera. Estimates of species per section are listed.

Key Words. classification, large-genera, Myrtaceae, systematics, taxonomy.

\section{Introduction}

Currently comprising c. 850 accepted species (World Checklist of Selected Plant Families (WCSP) 2017) but reduced according to the most recent morphological and phylogenetic studies (Staggemeier et al. 2015; Santos et al. 2016; Wilson et al. 2016; Vasconcelos et al. 2017; Lima et al. in prep.; Amorim et al. in prep.) to c. 800 species, Myrcia s.l. (sensu Lucas et al. 2007, 2011) is the fourth largest genus of Myrtaceae after Eucalyptus, Eugenia and Syzygium, and one of the largest exclusively Neotropical genera. Taken in this sense, it is a monophyletic group (Santos et al. 2016) including the previously accepted genera Calyptranthes, Marlierea and Gomidesia and their synonyms. The rationale and justification for this circumscription is detailed elsewhere (Lucas et al. 2007, 2011). The nomenclatural conservation of Myrcia over Calyptranthes (Lucas \& Sobral 2011) was approved by the General Committee for Botanical Nomenclature (Wilson 2017). Myrcia s.l. is a widespread Neotropical genus defined by the combined morphological characters of foliaceous cotyledons, a soft seed coat, bi- or trilocular ovaries (occasionally with $4-8$ locules) containing two ovules per locule and determinate inflorescences in panicles or dichasia, very rarely reduced to few or single flowers (e.g. Kollman \& Sobral 2006). Further taxonomic discussion and the history of previous sub-generic division within Myrcia s.l. is given by Lucas et al. (2011) and Santos et al. (2016).

Myrcia s.l. has high species diversity in the Amazon and the Caribbean, however, diversity is highest in the Brazilian Cerrado and Atlantic forest biomes (WCSP 2016) where it is of particular ecological importance (Mori et al. 1983), an indicator of total angiosperm diversity (Murray-Smith et al. 2009) and can be used to set conservation priorities (Lucas \& Bunger 2015). Myrcia species have a critical ecological role, sustaining a complex ecological network of interactions with insects (mainly bees) via their flowers and with a wide range of vertebrate frugivores from small birds to larger mammals that disperse their fleshy fruits (Nic Lughadha \& Proença 1996; Pizo 2002; Gressler et al. 2006; Staggemeier et al. 2017). Due to the size of the genus and morphological homogeneity within it, species of Myrcia s.l. are perceived as difficult to identify and/or study. Species are often omitted or mis-named in ecological inventories or surveys of Neotropical forests (e.g. Martini et al. 2007; Rigueira et al. 2013; Moro et al. 2014), a serious problem for biodiversity management and an impediment to research (Goodwin et al. 2015). The Web of Science (2016) lists 275

\footnotetext{
Accepted for publication 28 November 2017. Published online 26 March 2018

1 Royal Botanic Gardens, Kew, Richmond, Surrey, UK. e-mail: e.lucas@kew.org

2 Universidade do Estado do Amazonas, 69058-807, Manaus, Amazonas, Brazil.

3 Universidade Estadual de Campinas, Campinas, São Paulo, Brazil.

4 Universidade de Brasília, Brasília, Brazil.

5 Jardim Botânico de Brasília, Brasília, Brazil.

6 Universidade do Estado do Pará, Belém, Pará, Brazil.

7 Universidade Federal Rural de Pernambuco, Recife, Brazil.

8 Universidade Federal de São Carlos, Sorocaba, São Paulo, Brazil.

9 Universidade Federal Rural do Rio de Janeiro, Rio de Janeiro, Brazil.

10 Universidade Estadual Paulista "Júlio de Mesquita Filho", Rio Claro, Brazil.

11 Universidade Federal de São João Del-Rei, São João del-Rei, Minas Gerais, Brazil.
} 
publications based on the above-mentioned traditional genera of Myrcia s.l. This is in contrast to the nearly eight times more publications listed for the comparably sized genus, Rhododendron L. (Ericaceae). To stimulate, and now facilitate research, in particular monographic revision, of Myrcia s.l. it is desirable to provide a framework from which discrete groups of species can be selected for study.

The phylogenetic review based on a molecular phylogeny of Myrcia s.l. of Lucas et al. (2011) described nine morphologically coherent clades within the group. These clades now serve as manageable units, taken up in current discussion and used to delimit much-needed, subsequent systematic studies in the group (e.g. Staggemeier et al. 2015; Santos et al. 2016; Wilson et al. 2016; Lima et al. in prep.; Amorim et al. in prep.). The nine clades have a mixture of published or informal sectional names (Lucas et al. 2007) that have now passed into casual and in one case, premature use (Nic Lughadha et al. 2010). Sect. Myrcia results from de Candolle's division of Myrcia into two sections whilst sect. Aulomyrcia (O. Berg) Griseb. results from Grisebach's (1860) reduction of Aulomyrcia O. Berg to sectional status. Sect. Sympodiomyrcia M. F. Santos \& E. Lucas (Santos et al. 2016) is a product of recent taxonomic focus on that group. Provision of formal names for the remainder of these taxa is now a logical and necessary step to allow formal, systematic use in current and future studies.

\section{Materials and Methods}

The following classification follows the generic concept discussed in Lucas \& Sobral (2011) and the phylogenetic hypothesis based on combined evidence from sequences of the ITS and ETS regions of nuclear DNA and the $p s b \mathrm{~A}-t r n \mathrm{H}, t r n \mathrm{~L}-\mathrm{F}$ and $m a t \mathrm{~K}$ regions of the chloroplast genome presented by Lucas et al. (2011) supplemented by information from the expanded phylogenetic studies of Myrcia s.l. of Santos et al. (2016), Staggemeier et al. (2015), Wilson et al. (2016) and Lima et al. (in prep.; incorporating phylogenomic techniques) and also by morphological traits discussed in all of those studies. The species sampling of Lucas et al. (2011) was designed to maximise included morphological and geographical variation. The result includes species from almost all previously described supra-generic groups (see Lucas et al. 2011) but is biased geographically towards eastern Brazil due to the availability of collections from there.

\section{Results and analysis}

The analysis includes representative species from the Amazon and the Caribbean, however it is acknowledged that Myrcia is least well known from the Guayana shield and the western Amazon and it is from these areas that species remain most difficult to classify. Extensive herbarium study nevertheless reveals little morphology that cannot be readily accommodated in this scheme with the exception of species of the uniquely uni-locular Caribbean genus Mozartia Urb., currently in synonymy of Myrcia (WCSP 2016). Santos et al. (2016) however, demonstrate the affinities of Mozartia species to be with those of Myrcia sect. Aulomyrcia. Two remaining sources of phylogenetic and thus taxonomic uncertainty are firstly, the relationship of species such as Myrcia robusta Sobral (2007: 75) that consistently (Santos 2014; Santos et al. 2016; Lima et al. in prep.) emerge in their own clade with poorly supported relationships to other clades. Morphologically these species are very similar to sect. Reticulosae resulting in their inclusion in that section. This clade may well warrant description as a new section when it is better understood. Secondly, in Myrcia elevata M. F. Santos (in Santos et al. 2015: 103) the hypanthium extends above the summit of the ovary and tears at anthesis; the number of calyx lobes varies from five to four and they are reflexed after anthesis. These characters suggest a relationship with Myrcia sect. Aulomyrcia however, Santos et al. (2016) show that M. elevata emerges in the clade corresponding to Myrcia sect. Myrcia. Myrcia elevata has a pubescent floral disc that may reflect a relationship with Myrcia sect. Myrcia and other species, and specimens previously of unknown affinity, are now under consideration as a group that may also warrant future description at sectional level.

The clades defined in this hypothesis are diagnosable by unique morphological characters or combinations of these characters, although one or more may often be absent or poorly pronounced. In addition, clades are well supported by Bayesian posterior probabilities and bootstrap analysis (Lucas et al. 2011; Santos et al. 2016), although relationships between clades are less robust. Future analysis is likely to increase resolution between groups and it is predicted that newly included species will be recognised within these sections or as independent, species-poor clades meriting recognition at the same rank.

Assigning sectional names in a large, nomenclaturally fraught genus can be complicated. Priority for the autonym, the name of the section that includes the generitype (in this case Myrcia sect. Myrcia), dates from the first publication of any sectional name (ICN; McNeill et al. 2007). In Myrcia this is 1828, when de Candolle recognised two sections, both of which are now considered synonyms of sect. Myrcia (note, Lucas et al. (2011) erroneously suggest that the first sectional division of Myrcia was by Grisebach in 1864). As names have priority only at the rank at which they are published, genus names although published earlier, could not take priority over the names of published sections. With these rules and the objective 
Table 1. Current species numbers for species allocated to each section of Myrcia s.I. Numbers in brackets are additional species uncertainly placed in the section.

\begin{tabular}{lr}
\hline \hline Section & Number of species \\
\hline Aulomyrcia & $140(11)$ \\
Calyptranthes & $277(2)$ \\
Gomidesia & $57(6)$ \\
Aguava & 32 \\
Myrcia & $120(19)$ \\
Eugeniopsis & $22(2)$ \\
Sympodiomyrcia & 26 \\
Reticulosae & $23(2)$ \\
Tomentosae & $9(2)$ \\
Section unknown or not Myrcia s.l. & 24 \\
Total & 774 \\
\hline
\end{tabular}

of nomenclatural stability in mind, we propose the following classification, dividing Myrcia into nine sections. For names for which have not already been assigned types, types are designated. Some of the proposed sections may be split after future analysis but their names will be retained by the residual group that includes the type.

A key to the sections of Myrcia s.l. is provided followed by a diagnosis of each section and short discussion; finally, an estimate of current numbers of species per section is provided (Table 1). Species were assigned to sections using the clades returned from molecular analysis as a guide to natural species groupings (thus clades correspond to sections; see Fig. 1) and assigning species to each section after study of types, specimens and protologues. Species placement per section fluctuates as researchers adjust analyses and concepts but it is unlikely that these proportions will change radically in the future. A list of species per section will be published after nomenclatural transfers from Marlierea and Calyptranthes are complete.

\section{Taxonomic Treatment}

Myrcia DC. (de Candolle 1827: 401) nom. cons. Lectotype: M. bracteolaris (Poir.) DC. designated by McVaugh (1956: 143).

Aguava Raf. (Rafinesque 1838: 107). Type: Aguava guianensis (Aubl.) Raf. Eugenia guianensis Aubl., Hist. Pl. Guiane 1: 506 (Aublet 1775).

Aulomyrcia O. Berg (1855: 35). Type: Aulomyrcia multiflora (Lam.) O. Berg. Eugenia multiflora Lam., Encycl. 3: 202 (Lamarck 1789).

Calyptranthes Sw. (Swartz 1788: 79.). Type: Calyptranthes chytraculia (L.) Sw. Myrtus chytraculia L., Syst. Nat. ed. 10: 1056 (Linnaeus 1759).

Cumetea Raf. (Rafinesque 1838: 106). Type: Cumetea alba Raf. Gomidesia O. Berg (1855: 5). Type: Gomidesia spectabilis (DC.) O. Berg. (1857: 12) designated by McVaugh (1956:
141). Myrcia spectabilis DC., Prodr. 3: 248 (de Candolle 1828).

Marlierea Cambess. in A. St. Hil. (Saint-Hilaire 1829: 373, t. 156). Type: Marlierea suaveolens Cambess.

Krugia Urb. (Urban 1893: 375). Type: Krugia elliptica (Griseb.) Urb. Marlierea elliptica Griseb., Fl. Brit. W. I.: 233 (Grisebach 1860).

Mozartia Urb. (Urban 1923: 87). Type: Mozartia gundlachii (Krug \& Urb.) Urb. Myrcia gundlachii Krug \& Urb., Bot. Jahrb. Syst. 19: 581 (Urban 1895). Rubachia O. Berg (1856: 11), p.p., (see explanation in Lucas et al. (2016). Type: Rubachia spiciflora O. Berg.

Trees, shrubs or sub-shrubs; hairs simple, sometimes dibrachiate; inflorescence usually a regularly branching panicle but sometimes very reduced, terminal flowers usually in groups of three or in a sub-opposite arrangement upon the rachis to form a spike; bracts and bracteoles rounded or acute, caducous or sometimes persistent after fruit fall; cataphylls present or not at leaf nodes; perianth (0 -) $4-5$ (- 7)-merous, hypanthium extending into a tube beyond the ovary, calyx lobes free or partially or totally fused, opening by longitudinal or transverse tearing or circumscissile and falling as a calyptra at anthesis; disc flat and hairy or glabrous with hypanthium extending into a tube beyond the ovary; stamens many, usually less than 200; ovary usually bi- to tri-locular (rarely $4-8$ locules) with 2 (rarely 1 or $3-8$ ) ovules per locule; ovules arising at a single point on the septum, usually slightly below the mid-point; anthers tetrasporangiate and bilocular at anthesis with thecae of equal height or vertically displaced, often with an apical oil gland; fruit a fleshy berry, globose or cylindrical usually with persistent calyx lobes, cotyledons foliaceous and folded, encircled by a long hypocotyl; testa soft; scalariform plates absent.

1. Myrcia sect. Calyptranthes $(S w$.) A. R. Lourenço $\mathcal{E} E$. Lucas stat. nov.

http:/ /www.ipni.org/urn:Isid:ipni.org:names:77173693-1

Calyptranthes Sw., Prodr. 5: 79 (Swartz 1788). Type: Calyptranthes chytraculia (L.) Sw. (Swartz 1788: 79). Basionym: Myrtus chytraculia L., Syst. Nat., ed. 10: 1056 (Linnaeus 1759).

Mitranthes O. Berg. synon. nov. (1856: 136). Type: Mitranthes ottonis O. Berg.

Trees or shrubs bearing pale yellow to red or brown, simple or often t-shaped, bristling trichomes; branch- 


\section{Key to the sections of Myrcia s.l.}

1. Floral disc pilose, hypanthium apparently not, or very shortly extended above summit of the ovary $\ldots \ldots \ldots \ldots \ldots$ Floral disc glabrous (exceptionally with hairs at base of style), hypanthium extended above summit of the ovary .3

2. Floral disc flat and covered in stiff trichomes, also visible in fruit; staminal ring thickened, usually comprising more than $60 \%$ of disc; anthers with equal sized thecae that recurve and open fully at dehiscence; fruits mostly markedly longer than wide, occasionally globose $\ldots \ldots \ldots \ldots \ldots \ldots \ldots \ldots \ldots \ldots \ldots \ldots \ldots \ldots \ldots \ldots \ldots \ldots \ldots \ldots \ldots \ldots \ldots \ldots \ldots \ldots \ldots \ldots$

Floral disc flat to concave with appressed hairs, also visible in fruit; staminal ring comprising no more than $30 \%$ of disc; anthers often with vertically displaced thecae and retaining curvature at dehiscence; fruits globose .... sect. 3. Gomidesia

3. Calyx lobes partially or completely fused in the bud, tearing on opening or falling as a calyptra; or if free, central point of attachment to flower narrower than width of sepal with lateral, horizontal fissures between lobe and hypanthium rim. Fruiting calyx with or without calyx lobe remains $\ldots \ldots \ldots \ldots \ldots \ldots \ldots \ldots \ldots \ldots \ldots \ldots \ldots$

Calyx lobes free in the bud, opening regularly without tearing, not falling as a calyptra; fruits with distinct,

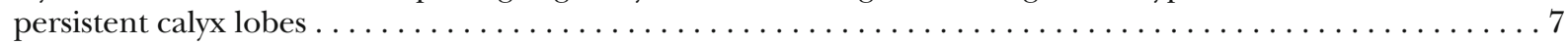

4. Inflorescence with exclusively opposite flowers; vegetative branching usually sympodial, cataphylls usually

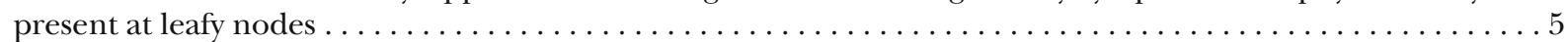

Inflorescence with alternate or sub-opposite flowers; vegetative branching not sympodial, cataphylls occasional

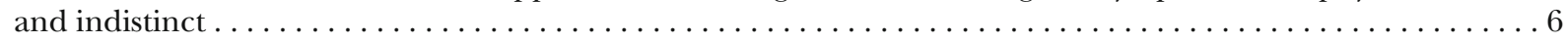

5. Calyx fused into a calyptra, falling completely at anthesis or remaining attached at a single point on rim; fruiting calyx without or occasionally with calyptra remains ................ Calyptranthes

Calyx lobes free, not fused into a calyptra, attachment at central point of lobe narrower than total width with horizontal fissures between lobe and hypanthium rim or rarely (Myrcia insigniflora) tearing vertically through it $\ldots \ldots \ldots \ldots \ldots \ldots \ldots \ldots \ldots \ldots \ldots \ldots \ldots \ldots \ldots \ldots \ldots \ldots \ldots \ldots \ldots \ldots \ldots \ldots$ sect. 7. Sympodiomyrcia

6. Trichomes usually reddish; leaf surfaces often markedly discoloured in dried material, pellucid dots densely aggregated, young branchlets often mottled by darkened lenticels; inflorescence usually a regular, triangular panicle, never markedly

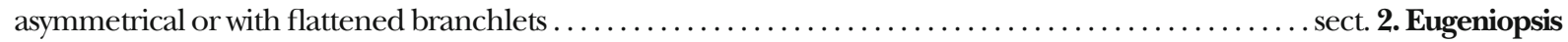

Trichomes not reddish; leaf surfaces not markedly discoloured, pellucid dots not densely aggregated, young branchlets without darkened lenticels; inflorescence a regular, triangular panicle or long, markedly asymmetrically branched terminal paniculate whorls or with flattened branchlets emerging from leafy nodes in

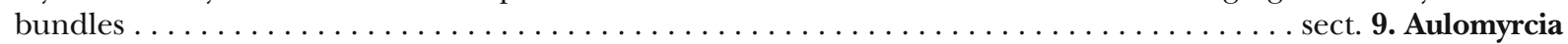

7. Ovary 2-locular, staminal ring glabrous, comprising less than $30 \%$ of total disc width $\ldots \ldots \ldots \ldots$

Ovary 3-locular, staminal ring pubescent or rarely glabrous, comprising more than $30 \%$ of total disc width ......... 9

8. Hypanthium often constricted below the disc in bud; calyx lobes acute and strongly reflexed at anthesis appearing distinctly star-shaped particularly in fruit; leaves often concentrated and whorled at ends of branchlets, giving a congested appearance, as in Prunus, whorls subtended by brachyblasts . . . . . . . . . . . . . sect. 8. Tomentosae Hypanthium not constricted below the disc; calyx lobes various; leaves evenly distributed over branchlets, not congested,

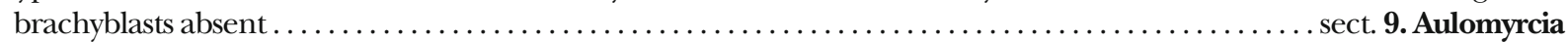

9. Leaves distinctly reticulate, veins raised both abaxially and adaxially, often with large and very distinct gland dots; entire plant often covered in a grey or reddish-brown felted hairs; staminal ring and often base of style lightly to

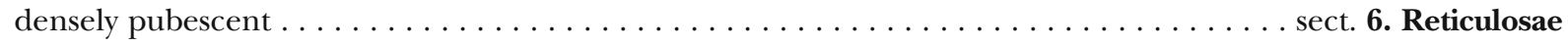

Venation not markedly reticulate, gland dots not notably distinct; plant usually not densely pubescent; staminal ring and style base glabrous $\ldots \ldots \ldots \ldots \ldots \ldots \ldots \ldots \ldots \ldots \ldots \ldots \ldots \ldots \ldots \ldots \ldots \ldots \ldots$

lets compressed or flattened to terete, sometimes two to four-winged with distal ends of wings between the leaf-bases at opposite sides of a node, often bearing lenticels; branching sympodial, frequent in vegetative and fertile branches; bracteoles linear, rounded or triangular and acute, usually caducous; inflorescence paniculate, often with an abortive, congested terminal primary axis or occasionally reduced with a single terminal flower, flowers opposite, terminal flowers in groups of three; buds apiculate; petals $0-2(-5)$, small, calyx fused and calyptrate, circumscissile and falling as a calyptra at anthesis, or remaining attached by a small piece of tissue at one side of the hypanthium; anther thecae symmetrical, reversing curvature on dehiscence, exposing interior of sacs as a convex surface; floral disc glabrous; staminal ring narrow, usually comprising less than $30 \%$ of total disc width; hypanthium glabrous internally, extending into a turbinate tube beyond the ovary; ovary bi-locular (rarely $3-4$, in species described as Mitranthes), with 2 ovules per 


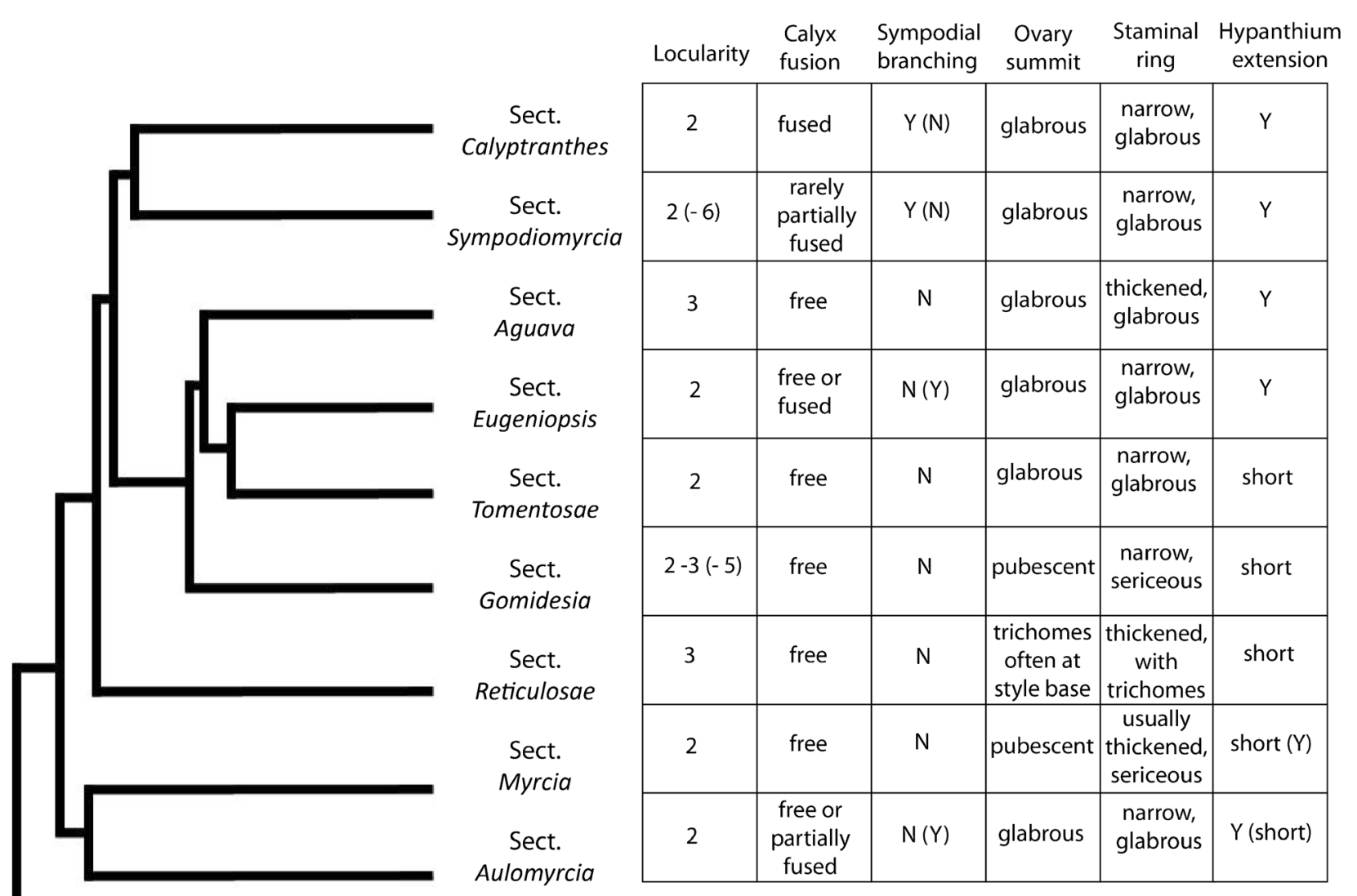

Fig. 1. Summarised phylogenetic tree of Myrcia s.l. modified from Santos et al. (2017) and Lima et al. (2017) with generalised key diagnostic characters for each Myrcia section. $\mathrm{N}=\mathrm{No} ; \mathrm{Y}=\mathrm{Yes}$.

locule; fruits globose with persistent apical hypanthium tube, calyptra generally falling or occasionally still attached at one side of the rim.

DISTRIBUTION. Moist forests (Amazon and Atlantic) and cerrado (including gallery forest) of Central and South America and throughout the Caribbean; relatively few species extending to associated drier habitats.

NOTES. Section Calyptranthes comprises plants with wide variation in leaf and inflorescence structure but all with a perfect calyptra. Wilson et al. (2016) use DNA sequence data of a representative species sample to show that the majority of species described as Calyptranthes emerge in this clade. To date, a single species with inflorescences that do not match the above description (Wilson et al. 2016) emerges in Myrcia sect. Aulomyrcia. The same study shows a pattern of evolutionary distinction between a clade of Caribbean and Amazonian species and those of the Atlantic forest and Cerrado. Some Myrcia s.l. species, particularly from the Amazon and Guayana shield, (e.g. Marlierea uniflora, Marlierea salticola) have completely closed buds that tear open irregularly at anthesis leaving several portions of calyx 'lobe', one often markedly larger and interpreted as a calyptra by previous authors. These species require further study, including with molecular approaches.
Berg (1855 - 1856) described the multilocular, calyptrate genus Mitranthes without fruit. McVaugh (1968) then treated some Mitranthes, subsequently collected in fruit, as Psidium based on embryo characters but noted multilocular, calyptrate species with foliaceous, folded embryos that resembled Myrcia. On the basis of this confusion, McVaugh (1968) finally placed Mitranthes among his 'imperfectly known genera'. Examination of these 'myrcioid' Mitranthes in the herbarium and in the field revealed them to strongly resemble species of section Calyptranthes in their extremely pronounced and regular sympodial branching and perfect calyptra as well as pale brown to red bristling trichomes. Species described as Mitranthes have larger flowers and fruits than those of section Calyptranthes (for images, see http:// myrcia.myspecies.info/). Detailed taxonomic and nomenclatural summaries of Calyptranthes can be found in McVaugh (1958) and in Rosário et al. (2014); the latter work provides additional characterisation to the original authorship.

\section{Myrcia sect. Eugeniopsis (O. Berg) M. F. Santos $\mathcal{E}$ E. Lucas comb. nov.}


http://www.ipni.org/urn:lsid:ipni.org:names:77173695-1

Eugeniopsis O. Berg, Linnaea 27: 80 (1855). Type: Myrcia multipunctata Mazine (in Mazine et al. 2014: 99). Basionym: Eugenia laevigata DC. (de Candolle 1828: 283). Marlierea subg. Eugeniopsis (O. Berg) Kiaersk. (Kiaerskou 1893: 50)

Marlierea sect. Eugeniopsis (O. Berg) Nied. (Niedenzu 1893: 76).

Marlierea sect. Pseudocalyptra D. Legrand (1975: 7). Type: Marlierea eugeniopsoides (D. Legrand \& Kausel) D. Legrand (1975: 7).

Trees or shrubs, hairs usually reddish and t-shaped; pellucid dots dense on leaves and reproductive structures; branchlets terete, often bearing lenticels; branching usually monopodial (rarely sympodial) bracteoles rounded or acute, usually caducous; inflorescence usually a regularly branching panicle with an abortive, congested terminal primary axis, terminal flowers in groups of three; buds clavate (rarely turbinate or globose); petals $(4-) 5$, calyx partially fused (calyx lobes rarely free or completely fused), tearing open parallel to hypanthial tissue, tearing usually regularly; anther thecae of equal height, reversing curvature on dehiscence, exposing interior of sacs as a convex surface; floral disc glabrous; staminal ring narrow, usually comprising less than $30 \%$ of total disc width; hypanthium extending into an abruptly flared tube beyond the ovary; ovary bi-locular with 2 ovules per locule; fruits globose or obovoid with persistent, apical hypanthium tube, calyx remains generally falling.

DISTRIBUTION. Atlantic Forest with occasional occurrences in campos rupestres.

NOTES. Myrcia sect. Eugeniopsis species are united by the following suite of characters that are not always all present: leaves with open venation, distinct, regular, medium sized gland dots, leaf mid-vein and young branchlets distinctively covered in lenticels, inflorescence usually regularly branching, floral buds clavate (rarely globose or turbinate), calyx lobes partially fused (rarely totally fused or free) and deciduous parallel to the hypanthium ring. Myrcia sect. Eugeniopsis includes most species previously described as Eugeniopsis O. Berg (1855 - 56, 1857 - 58; see Lucas et al. 2011) but also Myrcia eugeniopsoides (D. Legrand \& Kausel) Mazine and Myrcia oblongata DC. Berg (1855 - 56, 1857 58) treated three myrcioid genera with tearing calyces, describing Rubachia as well as Eugeniopsis. Berg distinguished Marlierea by its completely or nearly completely closed bud whereas Rubachia and Eugeniopsis were distinguished by their short sepals in bud, $3-5$ sepals in the case of Rubachia that eventually tear to the summit of the ovary, and 4 sepals in Eugeniopsis that tear more or less regularly into the hypanthium without reaching the ovary. Bentham \& Hooker (1865) included the latter two genera in a more inclusive Marlierea before Kiaerskou (1893) and Niedenzu (1893) circumscribed three (homonym) generic subdivisions (subgenera or sections, respectively) within Marlierea:
Eumarlierea, Rubachia and Eugeniopsis. Legrand (1962) recognised only Marlierea section Marlierea (with two subsections; subsect. Clausae, bud closed, tearing into $4-$ 5 lobes, and subsect. Apertae, bud open, tearing into (3) 4 5 lobes, with Rubachia in the synonymy of the latter subsection) and section Eugeniopsis, eventually describing a third section, Pseudocalyptra (Legrand 1975) to house Marlierea eugeniopsoides after its transfer from Calyptranthes.

\section{Myrcia sect. Gomidesia (O. Berg) B. S. Amorim $\mathcal{E} E$ E. Lucas comb. \& stat. nov.}

http:/ /www.ipni.org/urn:lsid:ipni.org:names:77173711-1

Gomidesia O. Berg, Linnaea 27: 5 (1855). Type: Gomidesia spectabilis (DC.) O. Berg. (1857: 12) designated by McVaugh (1956: 141). Basionym: Myrcia spectabilis DC., Prodr. 3: 248 (1828).

Cerqueiria O. Berg (1856: 5). Type: Cerqueiria sellowiana O. Berg.

Trees or shrubs, often covered in a brownish pubescence, hairs simple or unevenly dibrachiate; branchlets terete; branching usually monopodial; bracteoles usually caducous; inflorescence formed from conflorescences of $2-6$ (8 ) generally symmetrical uniflorescences; buds globose; perianth usually 5 -merous, petals and equally sized sepals distinct and imbricate, abaxially pubescent, calyx lobes generally truncate or rounded, rarely acute; anthers with the internal sac of each pair of locules clearly or slightly overtopping the external sac, open thecae retaining or losing curvature on dehiscence but never reversing and exposing interior of sacs as a convex surface; floral disc pubescent, usually with a light covering of appressed hairs; staminal ring narrow, usually comprising less than $30 \%$ of total disc width; hypanthium internally glabrous or pubescent, extending into a short tube beyond the ovary; ovary $2-3$ (-5)-locular with 2 ovules per locule; fruits globose, often pubescent, with persistent calyx lobes erect at apex.

DISTRIBUTION. Atlantic coastal and associated lowland, montane and gallery forests and cerrado, extending to the Amazon and Caribbean.

NOTES. Species of section Gomidesia are defined by the frequent, but not exclusive, combination of silky white, yellow, brown or red pubescence, specialised vertically displaced anthers, a prolonged, internally pubescent hypanthium and usually truncate, erect calyx lobes, particularly in fruit. Abaxial venation in this group is often prominent. The genus Gomidesia was described based almost entirely on the presence of anthers with displaced thecae (Nic Lughadha 1997) but in some species this character is not pronounced. Nic Lughadha et al. (2010) discuss Myrcia 'section Gomidesia' even though it was not then published at this rank. The name is here validated. Amorim et al. (in prep.) will provide a more detailed phylogenetic review of this section. 
4. Myrcia sect. Aguava (Raf.) D. F. Lima E E. Lucas comb. \& stat. nov.

http:/ /www.ipni.org/urn:lsid:ipni.org:names:77173712-1

Aguava Raf., Sylva Tellur:: 107 (Rafinesque 1838). Lectotype, designated here: Aguava guianensis (Aubl.) Raf. (Rafinesque 1838: 107). Basionym: Eugenia guianensis Aubl., Hist. Pl. Guiane 1: 506 (Aublet 1775).

Atomostigma Kuntze (1898: 76). Type: Atomostigma mattogrossense Kuntze.

Calyptromyrcia O. Berg (1856: 34). Type: Calyptromyrcia cymosa $\mathrm{O}$. Berg

Trees, shrubs or woody sub-shrubs, hairs simple; branchlets usually terete or sometimes tetrangular; branching not sympodial; bracteoles rounded or acute, usually caducous; inflorescences usually a symmetrical, regularly branching triangular panicle; buds globose; perianth 5-merous, petals and sepals distinct and imbricate, sepals internally pubescent; anther thecae of equal heights, reversing curvature on dehiscence, exposing interior of sacs as a convex surface; floral disc glabrous; staminal ring glabrous and somewhat thickened, usually comprising $30-40 \%$ of total disc width; hypanthium internally glabrous extending into a flared tube beyond the ovary; ovary consistently tri-locular with 2 ovules per locule; fruits globose, with persistent calyx lobes and flared hypanthium tube at apex.

DISTRIBUTION. Common throughout the distribution of Myrcia s.l., found in all tropical biomes including very wet and dry habitats.

NOTES. Myrcia sect. Aguava is well defined by the characters of a regularly branching multi- or pauciflorous panicle, the hypanthium extended beyond the ovary and internally glabrous, five non-tearing, regular calyx lobes, a moderately thickened, glabrous staminal ring and a tri-locular ovary. Individuals are usually glabrous or glabrescent. The most common and widespread species of this group is Myrcia guianensis which has a steadily increasing synonymy (Lima 2017, Lima et al. in prep.). Myrcia sect. Aguava differs from the other trilocular sect. Reticulosae in leaf characters (thicker leaves with more prominent venation and large gland-dots in the latter group) and in pubescence on the staminal ring and style base (trichomes are present on these structures in the latter group). Myrcia sect. Aguava differs from sect. Aulomyrcia in its venation (mid-vein impressed in the latter group while flat or adaxially prominent in sect. Aguava) and its locularity (bilocular in the latter group).

\section{Myrcia sect. Myrcia. Type: Myrcia bracteolaris (Poir.) DC.}

Myrtus bracteolaris Poir. in Lam., Encycl. 4: 411 (Lamarck 1798).
Myrcia sect. Oocarpae DC. (de Candolle 1828: 255). Lectotype designated here: Myrcia formosiana DC. (de Candolle 1828: 255).

Myrcia sect. Sphaerocarpae DC. Type: M. bracteolaris (Poir.) DC. (de Candolle 1828: 245).

Myrcia sect. Debracteatae Nied. (Niedenzu 1893: 75). Lectotype designated here: Myrcia splendens DC. (de Candolle 1828: 244).

Myrcia sect. Bracteatae O. Berg ex Nied. Lectotype designated here: Myrcia bracteata (Rich.) DC. (de Candolle 1828: 245).

Eugenia bracteata Rich., Actes Soc. Hist. Nat. Paris 1: 110 (Richard 1792).

Cumetea Raf. (Rafinesque 1838: 106). Lectotype designated here: Cumetea alba Raf.

Calycampe O. Berg (1856: 129). Type designated by McVaugh (1956: 138): Calycampe latifolia O. Berg

Myrcia sect. Eumyrcia Griseb. nom. inval. (Art. 21.3 ICBN (McNeill et al. 2012)).

Trees, shrubs or woody sub-shrubs; hairs simple; branchlets terete or sometimes tetrangular; branching not sympodial; venation often closed with little distinction between primary and secondary veins; bracteoles rounded or acute, usually caducous; inflorescences usually a symmetrical, regularly branching triangular panicle; buds globose; perianth 5-merous, petals and sepals distinct and always free, imbricate and acute, abaxially and/or adaxially pubescent, adaxial hairs frequently silver, silky and appressed; anther thecae of equal heights, reversing curvature on dehiscence, exposing interior of sacs as a convex surface; floral disc flat and pubescent, typically hard to distinguish from broad, densely sericeous staminal ring comprising $60 \%$ or more of disc width, occasionally less thick but always sericeous with stiff hairs; hypanthium short, scarcely extending into a tube beyond the ovary, outer surface with appressed, silky hairs to copiously lanate; ovary bi-locular with 2 ovules per locule; fruits cylindrical, with persistent calyx lobes held separated and erect at apex.

DISTRIBUTION. Common throughout the distribution of Myrcia s.l.

NOTES. Section Myrcia is a clearly defined group with five free calyx lobes and almost always, a distinctive broad, flat, pubescent disc and commonly cylindrical, rarely globose fruits. The most common and widespread species is Myrcia splendens, however there are many other very distinct species within the group. M. splendens is a species within which it is extremely difficult to draw morphological species boundaries and has become something of a 'dustbin' species to which widely differing specimens have been assigned without exhaustive study. This section is under focused study by Lima dos Santos (in prep.). 
6. Myrcia sect. Reticulosae D. F. Lima $\mathcal{E}$ E. Lucas sect. nov. Type: Myrcia reticulosa Miq. (Miquel 1850: 794).

http://www.ipni.org/urn:lsid:ipni.org:names:77173713-1

Trees or shrubs; often covered in a grey or reddishbrown felt, particularly on young branches, hairs simple; branchlets terete; branching not sympodial; venation distinctly rugose, often with one or few large and distinct glands per vein reticulation, veins raised abaxially and adaxially; bracteoles rounded or acute, usually caducous; inflorescences usually a symmetrical, regularly branching triangular panicle; buds globose; perianth 5-merous, petals and sepals distinct and imbricate, sepals internally pubescent, often acute and ciliate; anther thecae of equal heights, reversing curvature on dehiscence, exposing interior of sacs as a convex surface; floral disc pubescent at the base of style or glabrous; staminal ring with trichomes, thickened, usually comprising $30-40 \%$, occasionally a little more, of total disc width; hypanthium internally glabrous, extending into a somewhat flared tube beyond the ovary; ovary tri-locular with 2 ovules per locule; fruits globose, often with persistent calyx lobes and the hypanthium tube flared at the apex.

DISTRIBUTION. Atlantic coastal forests, cerrado and campos rupestres.

NOTES. Species of sect. Reticulosae share several characteristics with sect. Aguava such as regularly branching inflorescences, regular calyx lobes and consistent tri-locularity. However, DNA-based evidence repeatedly supports independent origins for these clades (Lucas et al. 2011; Lima et al. in prep.), a pattern supported by morphological differences such as the former section having highly reticulate, textured leaves with large, widely spaced pellucid gland dots, an often waxy cover on the adaxial surface of the leaf and a consistently hairy staminal ring. Section Reticulosae currently includes species from a clade of uncertain placement, namely Myrcia maximiliana O. Berg, M. pulvinata B. S. Amorim, M. robusta Sobral, M. thomasii B. S. Amorim \& A. R. Lourenço and M. unana Sobral, Faria \& Villaroel; these species are placed here for now due to their congruent morphology.

7. Myrcia sect. Sympodiomyrcia M. F. Santos E E. Lucas (2016: 759). Type: Myrcia subcordata DC. (de Candolle 1828: 253).

Trees or shrubs; hairs dibrachiate; branching sympodial or monopodial; branchlets often terete or winged with distal ends of wings terminating at leaf petioles; cataphylls usually present at the base of internodes; bracteoles generally lanceolate or ovate, usually caducous; inflorescence a panicle, usually branching from a single point at the base, with two to more than ten branches of similar dimensions; terminal flowers in groups of three or often only one flower; buds turbinate or clavate (rarely globose); perianth (3-) $4-5$ (-7)-merous, calyx lobes internally glabrous or pubescent, usually distinct from the hypanthium, free, tearing regularly, parallel to rim of hypanthium upon opening, except in Myrcia insigniflora M. F. Santos (2014: 99); anther thecae of equal heights, reversing curvature on dehiscence, exposing interior of sacs as a convex surface; floral disc glabrous; staminal ring narrow, comprising less than $30 \%$ of total disc width; hypanthium internally glabrous, extending into a turbinate or clavate tube beyond the ovary; ovary bilocular with usually 2 ovules per locule, although occasional collections of $M$. subavenia are reported with ten seeds (Faria pers. comm.); fruits globose with persistent apical hypanthium tube, calyx lobes usually falling or remnants occasionally still attached.

DISTRIBUTION. Atlantic Forest, cerrado (campo rupestre and riparian forest, not savanna), and a disjunct distribution in the Guiana Shield.

NOTES. Section Sympodiomyrcia is clearly defined by the combined characters of: presence of cataphylls at the base of the internodes; inflorescence with sympodial basal branching in which two or more branches of similar dimensions are developed; inflorescence with apical branching always opposite; turbinate or clavate floral buds (rarely globose); the hypanthium elongated above the ovary and not tearing during anthesis and free calyx lobes that are deciduous parallel to the hypanthium rim. The free calyx lobes detach from the rim of the hypanthium in mature flowers and fruit, usually via horizontal fissures along the rim, suggesting a close relationship with section Calyptranthes. Sympodial branching (mostly found in the inflorescence basal branching) is also reminiscent of section Calyptranthes; bud shape and mature fruits are also similar particularly after removal of the calyx lobes. Myrcia insigniflora is an exception to these floral features with the hypanthium tearing vertically during anthesis and persistent calyx lobes. However, most characters of $M$. insigniflora are congruent with section Sympodiomyrcia including the presence of cataphylls and the architecture of the inflorescence.

8. Myrcia sect. Tomentosae E. Lucas $\mathcal{E}$ D. F. Lima sect. nov. Type: Myrcia tomentosa (Aubl.) DC. (de Candolle 1828: 245).

http:/ /www.ipni.org/urn:lsid:ipni.org:names:77173714-1

Eugenia tomentosa Aubl., Hist. Pl. Guiane 1: 504 (Aublet 1775). 
Trees, shrubs or woody sub-shrubs; hairs simple; branchlets terete; branching usually monopodial with leaves concentrated and whorled at ends of branchlets giving a congested appearance such as in Prunus, whorls commonly subtended by clusters of acute to elliptic brachyblasts; bracteoles usually triangular and sharply acute, usually persistent after fruit fall; inflorescence usually an asymmetrical, irregularly branching panicle giving a zig-zagged appearance and occasionally appearing spike-like; buds ovate, often with a constriction or slight constriction beneath ovary; perianth 5merous, sepals distinct, triangular, acute, imbricate and adaxially pubescent; anther thecae of equal heights, reversing curvature on dehiscence, exposing interior of sacs as a convex surface; floral disc glabrous; staminal ring narrow, comprising less than $30 \%$ of total disc width; hypanthium usually internally glabrous extending into a short tube beyond the ovary; ovary bi-locular with 2 ovules per locule; fruits globose, rarely exceeding $8 \mathrm{~mm}$ diam., with triangular calyx lobes strongly reflexed and appressed to fruit in a characteristic star shape.

DISTRIBUTION. Common throughout the distribution of Myrcia s.l.

NOTES. Section Tomentosae is a well-defined, widespread section but includes relatively few species. It is easily defined by buds with a distinct constriction below the ovary, small flowers and fruits relative to the other sections and the characteristic reflexing of the regular, free calyx lobes, in particular in fruit. Other distinctive characters are a pruinous indument at the base of branches and often congested branchlets interspersed with persistent bracts. The section is easy to define and distinct morpho-types can be recognised as separate species (e.g. Myrcia tomentosa (Aubl.) DC., M. laruotteana Cambess). Population level studies (Lima et al. 2015) show that a morphological continuum exists that agrees to some extent with geographical distribution and genetic variation within populations is greater than among populations. This implies that the populations are genetically similar and genetic flow takes place between them. Santos et al. (2016) indicate this to be one of the youngest clades in Myrcia s.l.; this may explain the lack of genetic distinction. The study concludes that clear morphological and genetic definition of species within this group is not straightforward task.

9. Myrcia sect. Aulomyrcia (O. Berg) Griseb. (Grisebach 1860: 234).

Aulomyrcia O. Berg, Linnaea 27: 35 (1855). Lectotype (designated by McVaugh 1956: 137): Myrcia multiflora (Lam.) DC. (de Candolle 1828: 244).

Eugenia multiflora Lam. (Lamarck 1789: 302).

Krugia Urb. (Urban 1893: 375). Type: Krugia elliptica (Griseb.) Urb.
Marlierea elliptica Griseb. (Grisebach 1860: 234).

Myrcia sect. Aulomyrcia Nied. as "Sect. 1. Eu-Aulomyrcia". Lectotype designated by Lucas et al. (2016): Myrcia pyrifolia (Desv.) Nied. (Niedenzu 1893: 76).

Eugenia pyrifolia Desv. ex Ham. (Hamilton 1825: 44).

Marlierea Cambess. in A. St. Hil. (Saint-Hilaire 1829: 373). Type: Marlierea suaveolens Cambess.

Mozartia Urb. (Urban 1923: 87). Type: Mozartia gundlachii (Krug. \& Urb.) Urb.

Myrcia gundlachii Krug \& Urb. (Urban 1895: 581).

Marlierea sect. Myrciopsis McVaugh (1958: 79) [Unintentionally published as sect. Myrcioides (McVaugh 1963)]. Type: Marlierea bipennis (O. Berg) McVaugh (1956: 189).

Myrciaria bipennis O. Berg (1862: 259).

Myrcia sect. Armeriela McVaugh (1968: 378). Type: Myrcia inaequiloba (DC.) Lemée (1954: 150).

Eugenia inaequiloba DC. (de Candolle 1828: 282).

Rubachia O. Berg (1856: 11), p.p., (see explanation in Lucas et al. 2016). Type: Rubachia spiciflora O. Berg.

Trees or shrubs; hairs mostly simple, dibrachiate in some species; branchlets terete; branching usually monopodial; bracteoles usually triangular and acute, usually persistent after fruit fall; inflorescence variable from a triangular, asymmetrical panicle to a single terminal whorl representing a compression of all primary inflorescence nodes, with long, irregularly branched primary axes that appear asymmetrical, often with a zig-zagged appearance and occasionally appearing spike-like, occasional clusters of shorter panicles with flattened rachises emerging from leaf nodes, apparently in clumps; buds clavate or ovate; perianth 4 - 5-merous, calyx lobes free to partially or completely fused, often irregularly sized, opening regularly or irregularly tearing vertically through the calyx and hypanthial tissue, leaving calyx lobes of markedly different sizes or of regular triangles in a 'star' shape, where tears are deep, staminal scars appear at the tips of calyx lobes; anther thecae of equal heights, reversing curvature on dehiscence, exposing interior of sacs as a convex surface; floral disc glabrous; staminal ring narrow usually glabrous, occasionally pubescent, comprising less than $40 \%$ of total disc width; hypanthium extending somewhat beyond the ovary but inconspicuous after deep tearing; ovary bi-locular with 2 ovules per locule; fruits globose.

DISTRIBUTION. Amazon forest, the Guayana shield, Caribbean and the Atlantic coastal forests (particularly Bahia and Espírito Santo), extending to associated drier habitats. NOTES. Detailed discussion of the taxonomic and nomenclatural history of Myrcia section Aulomyrcia can be found in Lucas et al. (2016).

\section{Acknowledgements}

We recognise with gratitude, the input of an anonymous reviewer with scrupulous attention to nomenclatural 
detail. This work is the culmination of nearly ten years of taxonomic consideration. People without whose input this paper would not have been possible from the laboratory, herbarium and field, are very many. We gratefully acknowledge particular assistance from Daniela Zappi, Christine Wilson, Jomar Jardim, Lidyanne Aona, Jair Faria, Fiorella Mazine, Diego Bogarin, Keron Campbell, Jim Clarkson, Teodoro Clase, Tracey Commock, Lazlo Cziba, Dion Devey, Edith Kapinos, Judeen Meikle, William Milliken and Felix Forest. Matheus F. Santos received a Post-doctoral Fellowship (PDJ) from CNPq Brazil (150217/2016-1). Duane F. Lima received sandwich and $\mathrm{PhD}$ fellowships from CNPq (205237/2014-2; 165669/2013-6). These grants contributed directly to this research.

Open Access This article is distributed under the terms of the Creative Commons Attribution 4.0 International License (http://creativecommons.org/licenses/by/ 4.0/), which permits unrestricted use, distribution, and reproduction in any medium, provided you give appropriate credit to the original author(s) and the source, provide a link to the Creative Commons license, and indicate if changes were made.

\section{References}

Aublet, J. B. C. F. (1775). Histoire des plants de la Guiane Françoise. Tome 1. P. F. Didot jeune, Libraire de la Faculté de Médicine, Quai des Augustins, Londres, Paris. Bentham, G. \& Hooker, J. D. (1865). Myrtaceae. In: G. Bentham \& J. D. Hooker (eds), Genera Plantarum Vol. 1: 690 - 725. Reeve \& Co., London.

Berg, O. (1855 - 1856). Revision Myrtacearum Americae. Linnaea 27: 1 - 472.

— (1857 - 1859). Myrtaceae. In: C. F. P. von Martius (ed.), Flora Brasiliensis 14: 1 - 655. Oldenbourg, Leipzig.

- (1862). Linnaea 31: 259.

Candolle, de A. P. (1827). In: J. B. G. G. M. Bory (ed.), Dictionaire classique d'histoire naturelle 11: 378. Paris.

_ (1828). Myrtacae. In: A. P. de Candolle (ed.), Prodromus Systematis Naturalis Regni Vegetabilis Vol. 3: 207 - 296. Treuttel \& Würtz, Paris.

Gressler, E., Pizo, M. A., \& Morellato, L. P. C. (2006). Polinização e dispersão de sementes em Myrtaceae do Brasil. Brazil. J. Bot. 29: 509 - 530.

Grisebach, A. H. R. (1860). Flora of the British West Indian Islands. Reeve, London.

Goodwin, Z. A., Harris, D. J., Filer, D., Wood, J. R. \& Scotland, R. W. (2015). Widespread mistaken identity in tropical plant collections. Curr. Biol. 25: 1066 - 1067.

Hamilton, W. (1825). Prodromus plantarum Indiae Occidentalis: 44. Treuttel \& Würtz, London, Paris, Strasbourg.

Kiaerskou, H. (1893). Enumeratio Myrtacearum Brasiliensium. In: E. Warming (ed.), Symbolarum ad floram Brasiliae centralis cognoscendam, 39. Gjellerup, Copenhagen.

Kollmann, L. J. \& Sobral, M. (2006). Myrcia inconspicua (Myrtaceae), a new species from Espírito Santo, Brazil. Novon 16: $501-504$.

Kuntze, C. E. O. (1898). Revisio Generum Plantarum 3. Felix, Leipzig.

Lamarck, J. B. A. P. de M. (1789). Encyclopédie méthodique, Botanique, Supplément. Tome 3. Panckoucke, Paris; Plomteux, Liège.

(1798). Encyclopédie méthodique, Botanique, Supplément. Tome 4. Panckoucke, Paris; Plomteux, Liège.

Legrand, C. D. (1962). Sinopsis de las Especies de Marlierea del Brasil. Bot. Mus. Hist. Nat. Montevideo 3: $1-39$.

(1975). Miscelaneas Mirtologicas. Bradea 2: 5 - 7.

Lemée, A. M. V. (1954). Flore de la Guyanae Française 3. Paris.

Lima, D. F., Mauad, A. V. S., da Silva-Pereira, V., de Camargo Smidt, E. \& Goldenberg, R. (2015). Species boundaries inferred from ISSR markers in the Myrcia laruotteana complex (Myrtaceae). Pl. Syst. Evol. 301: 353 - 363.

- (2017). Estudos filogenéticos e taxonômicos em Myrcia DC. sensu latu (Myrtaceae), com ênfase no Clado Guianensis. Ph.D. Thesis, Universidade Estadual de Campinas.

Linnaeus, C. (1759). Systema Naturae ed. 10: 1056. Laurentii Salvii, Holmiae.

Lucas, E. J. \& Bünger, M. O. (2015). Myrtaceae in the Atlantic forest: their role as a 'model'group. Biodivers. Conserv. 24: 2165 - 2180.

-, Harris, S. A., Mazine, F. F., Belsham, S. R., Lughadha, E. M. N., Telford, A., Gasson, P. E. \& Chase, M. W. (2007). Suprageneric phylogenetics of Myrteae, the generically richest tribe in Myrtaceae (Myrtales). Taxon 56: 1105 - 1128.

- Matsumoto, K., Harris, S. J., Nic Lughadha, E. M., Bernardini, B. \& Chase, M. W. (2011). Phylogenetics, Morphology and evolution of the large genus Myrcia s.l. (Myrtaceae). Int. J. Pl. Sci. 172: 915 $-934$.

\& Sobral, M. (2011). Proposal to conserve the name Myrcia against Calyptranthes (Myrtaceae). Taxon 60: 605 - 605 .

—, Wilson, C. E., Lima, D. F., Sobral, M. \& Matsumoto, K. (2016). A conspectus of Myrcia sect. Aulomyrcia (Myrtaceae). Ann. Missori Bot. Gard. 101: $648-698$.

Martini, A. M. Z., Fiaschi, P., Amorim, A. M. \& da Paixão, J. L. (2007). A hot-point within a hot-spot: a high diversity site in Brazil's Atlantic Forest. Biodivers. Conserv. 16: 3111 - 3128.

Mazine, F., Santos, M. F. \& Lucas, E. (2014). New combinations and new names in Myrcia (Myrtaceae) for Flora of São Paulo state, Brazil. Phytotaxa 173: 97 - 100. 
McNeill, J., Redhead, S. A. \& Wiersema, J. H. (2007). Guidelines for proposals to conserve or reject names. Taxon 56: 249 - 252.

—, Barrie, F. R., Buck, W. R., Demoulin, V., Greuter, W., Hawksworth, D. L., Herendeen, P. S., Knapp, S., Marhold, K., Prado, J., Prud'homme van Reine, W. F., Smith, G. F., Wiersema, J. H. \& Turland, N. J. (2012). International Code of Nomenclature for algae, fungi, and plants (Melbourne Code). Regnum Veg. 154.

McVaugh, R. (1956). Tropical American Myrtaceae, notes on generic concepts and descriptions of previously unrecognized species. Fieldiana Bot. 29: $145-228$.

_ (1958). Myrtaceae. In: B. Maguire \& J. J. Wurdack, The Botany of the Guayana Highland - Part III. Mem. New York Bot. Gard. 10: 62 - 91.

(1963). Tropical American Myrtaceae, II. Notes on generic concepts and descriptions of previously unrecognized species. Fieldiana Bot. 29: 393 - 532.

(1968). The genera of American Myrtaceae an interim report. Taxon 17: $354-418$.

Miquel, F. M. W. (1850). Manipulus Stirpium Blanchetianarum in Brasilia collectarum. Linnaea 22: $793-807$.

Mori, S. A., Boom, B. M. \& de Carvalino, A. M. (1983). Ecological importance of Myrtaceae in an eastern Brazilian wet forest. Biotropica 15: 68 - 70.

Moro, M. F., Nic Lughadha, E., Filer, D. L., De Araujo, F. S. \& Martins, F. R. (2014). A catalogue of the vascular plants of the Caatinga Phytogeographical Domain: a synthesis of floristic and phytosociological surveys. Phytotaxa 160: 1 - 118.

Murray-Smith, C., Brummitt, N. A., Oliveira-Filho, A. T., Bachman, S., Moat, J., Lughadha, E. M. \& Lucas, E. J. (2009). Plant diversity hotspots in the Atlantic coastal forests of Brazil. Conserv. Biol. 23: 151 - 163.

Nic Lughadha, E. M. (1997). Systematic studies in Gomidesia (Myrtaceae). Ph.D. Thesis (unpubl.) University of St Andrews.

—_ \& Proença, C. (1996). A survey of the reproductive biology of the Myrtoideae (Myrtaceae). Ann. Missouri Bot. Gard. 83: 480 - 503.

— Slade, K., Jennings, L., Boudet-Fernandes, H. \& Lucas, E. (2010). Three new species of Myrcia section Gomidesia (Myrtaceae) from Espírito Santo, Brazil. Kew Bull. 65: 21 - 28.

Niedenzu, F. (1893). Myrtaceae. In: A. Engler \& K. Prantl, Nat. Pflanzenfam. 3: 57 - 105.

Pizo, M. A. (2002). The seed dispersers and fruit syndromes of Myrtaceae in the Brazilian Atlantic forest. In: D. J. Levey, W. R. Silva \& M. Galetti (eds), Seed dispersal and frugivory: ecology, evolution and conservation, pp. 129 - 143. CABI Publishing, Wallingford.

Rafinesque, C. S. (1838). Sylva Telluriana. Mantis Synopt. New genera and species of trees and shrubs of North America and other regions of the earth. Philadelphia.
Richard, L. C. M. (1792). Actes Soc. Hist. Nat. Paris 1: 110

Rigueira, D. M. G., da Rocha, P. L. B. \& Mariano-Neto, E. (2013). Forest cover, extinction thresholds and time lags in woody plants (Myrtaceae) in the Brazilian Atlantic Forest: resources for conservation. Biodivers. Conserv. 22: 3141 - 3163.

Rosario, A. S., Baumgratz, J. F. A. \& Secco, R. D. S. (2014). Taxonomic notes in Calyptranthes (Myrciinae; Myrtaceae) in the Brazilian Amazon. Phytotaxa 186: 158 - 165.

Santos, M. F. (2014). Biogeografia de Myrcia s.l., taxonomia e filogenia do clado Sympodiomyrcia (Myrtaceae). Ph.D. Thesis, Universidade de São Paulo.

Santos, M. F., Sano, P. T., Forest, F. \& Lucas, E. J. (2016). Phylogeny, morphology and circumscription of Myrcia sect. Sympodiomyrcia (Myrcia s.l., Myrtaceae). Taxon 65(4): 759 - 774.

—, Lucas, E., Sobral, M., \& Sano, P. T. (2015). New species of Myrcia s.l. (Myrtaceae) from Campo Rupestre, Atlantic Forest and Amazon Forest. Phytotaxa 222: 100 - 110 .

$\longrightarrow$, Lucas, E., Sobral, M., Sano, P. T., Buerki, S., Staggemeier, V. G. \& Forest, F. (2017). Biogeographical patterns of Myrcia sl (Myrtaceae) and their correlation with geological and climatic history in the Neotropics. Molec. Phylogenet. Evol. 108: $34-48$.

Saint-Hilaire, A. F. C. P. (1829). Flora Brasiliae Meridionalis 2. Apud A. Belin, Paris.

Sobral, M. (2007). Bol. Mus. Biol. Prof. Mello-Leitão 20: $75-77$.

Staggemeier, V. G., Cazetta, E. \& Morellato, L. P. C. (2017). Hyperdominance in fruit production in the Brazilian Atlantic rain forest: the functional role of plants in sustaining frugivores. Biotropica 49: 71 - 82 .

— Diniz-Filho, J. A. F., Forest, F. \& Lucas, E. (2015). Phylogenetic analysis in Myrcia section Aulomyrcia and inferences on plant diversity in the Atlantic rainforest. Ann. Bot. 115: 747 - 761.

Swartz, O. P. (1788). Nova Genera E Species Plantarum seu Prodromus 5, Stockholm, Uppsala \& Abo.

Urban, I. (1893). Krugia, eine neue Myrtaceengattung. Ber. Deutsch. Bot. Ges. 11: 376.

(1895). Addimenta ad cognitionem florae Indiae occidentalis, particular II. Bot. Jahrb. Syst. 19: $562-581$.

— (1923). Symbolae Antillanae: seu fundamenta florae Indiae occidentalis 9. Fratres Borntraeger, Berlin.

Vasconcelos, T. N., Prenner, G., Santos, M. F., Wingler, A. \& Lucas, E. J. (2017). Links between parallel evolution and systematic complexity in angiosperms - A case study of floral development in Myrcia sl (Myrtaceae). Perspect. Pl. Ecol. Evol. Syst. 24: $11-24$. 
Web of Science (2016). Thomson Reuters. apps. webofknowledge.com /. Accessed 25/02/2016.

Wilson, C. E., Forest, F., Devey, D. S. \& Lucas, E. J. (2016). Phylogenetic relationships in Calyptranthes (Myrtaceae) with particular emphasis on its monophyly relative to Myrcia s.l. Syst. Bot. 41: 378 - 386.
Wilson, K. L. (2017). Report of the General Committee: 16. Taxon 66: $189-190$.

World Checklist of Selected Plant Families (WCSP) (2017). The Board of Trustees of the Royal Botanic Gardens, Kew. <www.kew.org/wcsp>. Accessed 22/ 07/2017. 